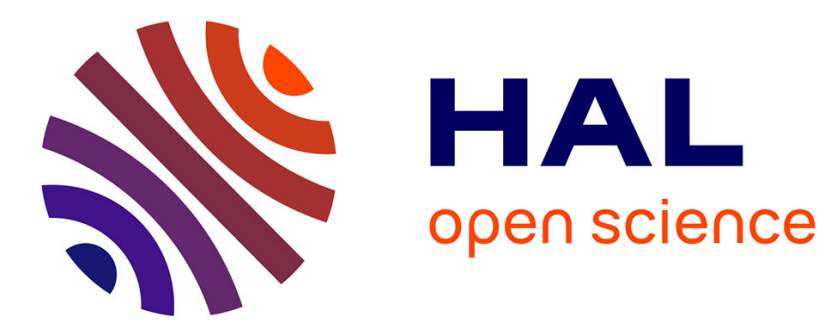

\title{
The case for a financial approach to money demand Xavier Ragot
}

\section{To cite this version:}

Xavier Ragot. The case for a financial approach to money demand. Journal of Monetary Economics, 2014, 62 (1), pp.94 - 107. 10.1016/j.jmoneco.2013.09.005 . halshs-00978785

\section{HAL Id: halshs-00978785 https://shs.hal.science/halshs-00978785}

Submitted on 8 Dec 2021

HAL is a multi-disciplinary open access archive for the deposit and dissemination of scientific research documents, whether they are published or not. The documents may come from teaching and research institutions in France or abroad, or from public or private research centers.
L'archive ouverte pluridisciplinaire HAL, est destinée au dépôt et à la diffusion de documents scientifiques de niveau recherche, publiés ou non, émanant des établissements d'enseignement et de recherche français ou étrangers, des laboratoires publics ou privés. 


\title{
The case for a financial approach to money demand
}

\author{
Xavier Ragot ${ }^{\mathrm{n}}$ \\ CNRS and Paris School of Economics, PSE, 48 Bd Jourdan, 75014 Paris, France
}

A bstract

The distribution of money across households is much more similar to the distribution of financial assets than to that of consumption expenditures. This is a puzzle for theories which directly link money demand to consumption. This paper shows that the joint distribution of money and financial assets can be explained in a heterogeneous-agent model where both a cash-in-advance constraint and financial adjustment costs, as in the Baumol-Tobin literature, are introduced. Studying each friction in turn, one finds that the financial friction explains more than $78 \%$ of total money demand.

\section{Introduction}

Why do households hold money? Various theories of money demand answer this question by focusing on the transaction role money plays in goods markets (e.g., shopping-time and cash-in-advance (CIA) models), transaction costs in financial markets (Baumol, 1952; Tobin, 1956) or simply assuming a liquidity role for money, as in models with money in the utility function (MIUF). In this paper, microeconomic data are used to quantify the contribution of the previous frictions to money demand. The shape of the distribution of money across households is indeed close to that of the distribution of financial wealth and dissimilar to that of consumption expenditures. Using a heterogeneous agent model, it is shown that reproducing such a money distribution allows quantifying the contribution of the frictions on the goods market and those in financial markets. In addition to its theoretical interest, the ability to reproduce the distribution of money is crucial for the assessment of the real and welfare effects of inflation.

In more detail, in both Italian and US data, the distribution of money (M1) is similar to that of financial wealth, and much more unequally distributed than that of consumption expenditures (as measured by the Gini coefficient, for example). In the US, the Gini coefficients are around .3 for the distribution of consumption expenditures across households, .5 for that of income, .8 for that of net wealth and .8 for that of money in 2004 . This stylized fact, further detailed below, holds for different definitions of money, various time periods, and after controlling for life-cycle effects. This distribution of money cannot be understood in standard macroeconomic models where money demand is modeled only via frictions on the goods markets, such as CIA, MIUF or shopping-time considerations. In these models, real money balances are proportional to consumption, and the distributions of money holdings and consumption should be equally distributed among households (i.e. have the same Gini coefficient). As shown below, this property holds even when more general transaction technologies in the goods market are considered, which may produce scale economies. 
In this paper, it is shown that a realistic joint distribution of consumption, money and financial assets can be reproduced when a friction in financial markets is introduced in addition to a transaction friction in goods markets. The friction in the goods market considered in the paper is a standard cash-in-advance constraint stating that household must hold money to consume. The friction in financial markets follows the Baumol-Tobin literature: money holdings can be freely adjusted, but there is a fixed cost of adjusting the quantity of financial assets. The initial Baumol-Tobin model considered a cost of going to the bank and thus modeled the choice between currency and bank deposits. Following many others, a fixed cost of adjusting the financial portfolio is here introduced in order to model the choice between money (including bank deposits) and other financial assets. This portfolio adjustment cost creates a financial motive to hold money: households hold monetary balances to smooth consumption without paying the fixed cost to adjust their financial portfolio. They go only infrequently to the financial market to replenish their money account, which is the standard result of the Baumol-Tobin model. ${ }^{1}$

This portfolio choice together with the cash-in-advance constraint is introduced into an economy where infinitely lived agents face uninsurable income fluctuations and borrowing constraints, a framework often described as the "BewleyHuggett-Aiyagari" environment. In this type of economy, households choose between two assets with different returns, but also different adjustment costs, in order to smoothen uninsurable idiosyncratic income fluctuations. This type of economy does not introduce life-cycle considerations and is thus well-suited for the analysis of heterogeneity within generations. The model is calibrated to reproduce the idiosyncratic income fluctuations faced by US households, as estimated by Heathcote (2005). The average inflation rate and the average return on the safe financial asset are their average values in 2004 in the US, a date at which the shape of the money distribution is available for US households. The adjustment cost and the severity of the cash-in-advance constraint are chosen to match the average quantity of money held by households in the US economy and the considerable inequality in money holdings.

The main result of this paper is that the model generates a realistic joint distribution of money and financial assets, when both frictions on financial and goods market are introduced. Removing in turn the two frictions, one finds that the friction on the goods market is necessary to explain why many households hold a small amount of money. The friction on financial market is necessary to explain why a few households hold large quantities of money. This last friction is thus necessary to generate the inequality in money holdings. The reasoning behind this result is that households go infrequently to financial markets to replenish their money holdings because of the adjustment cost. But as the opportunity cost of money holding is high, households decumulate rapidly their money holdings, and wait before going back to financial markets. As a consequence, a few households temporarily hold a large quantity of money, which contributes to money inequality. A stochastic cash-in-advance constraint is also introduced to generate a precautionary demand for money, as in Telyukova and Wright (2008). One still finds that a sizeable portfolio adjustment cost is necessary to reproduce the money distribution.

Finally, removing the transaction constraint on the goods market and the participation cost on the financial market, one finds that the transaction motives account for at most $22 \%$ of the total money stock, whereas the financial motives account for $78 \%$, motivating the title of this paper.

To my knowledge this paper is the first to reproduce a realistic distribution of money across households as an equilibrium outcome. It can be related to two strands of literature: the first is the Baumol-Tobin literature and the second is the heterogeneous-agent literature applied to monetary economics.

First, the Baumol-Tobin model has recently been used to explain money demand in quantitative models. Alvarez et al. (2002) introduce both a fixed transaction cost and a cash-in-advance constraint in a general-equilibrium setting. To simplify their analysis of the short-run effect of money injections, they assume that markets are complete and, consequently, that all agents hold the same financial wealth. This paper departs from the complete market assumption to match the money and wealth distribution. Bai (2005) revisits quantitatively the welfare cost of inflation in a Baumol-Tobin framework. Alvarez and Lippi (2009) use Italian household data to estimate a model where households face a cash-in-advance constraint, a fixed transaction cost and a stochastic cost of withdrawing money, which generates a precautionary demand for money. They show that this stochastic component improves the outcome of the model as compared to the deterministic Baumol-Tobin framework. In their analysis they take household cash expenditure as given to be able to tightly parameterize their model with data about cash management of Italian households. This paper instead tries to generate a realistic distribution of consumption, wealth and money in a simpler model, taking the income process as given. Finally, Kaplan and Violante (2011) use a Baumol-Tobin model in a heterogeneous-agent setting to analyze the effect of fiscal stimulus payments. They find that this model can reproduce a realistic marginal propensity to consume out of announced fiscal transfers. Although they do not consider the money distribution, their estimation of the financial participation cost is consistent with the value used in the paper. This paper is also related to the empirical work which has estimated money demand using household data. Erosa and Ventura (2002) introduce a fixed adoption cost of the technology to participate in financial markets, in addition to a shopping-time constraint. They estimate the adoption cost via various economic and econometric models using US household data. Attanasio et al. (2002) estimate a shopping-time model à la McCallum and Goodfriend (1987), using Italian household data.

\footnotetext{
${ }^{1}$ This friction alone generates a positive price for money in equilibrium, as the early works of Heller (1974) and Chatterjee and Corbae (1992) have shown
} 
Second, there is a literature which tries to explain the heterogeneity in money demand using incomplete insurance markets. ${ }^{2}$ The initial work in the heterogeneous-agent literature considered money as the only available asset for self-insurance against idiosyncratic shocks (Bewley, 1980, 1983; Scheinkman and Weiss, 1986; Imrohoroglu, 1992). More recent papers have introduced another financial asset with some additional frictions to justify positive money demand. Imrohoroglu and Prescott (1991) use a per-period cost, so that households hold either money or financial assets, but never both, and consider the real effects of various monetary arrangements. Erosa and Ventura (2002) introduce a cash-in-advance constraint and a fixed cost of withdrawing money from financial markets to study the inflation tax, but they do not characterize the money distribution. Akyol (2004) analyses an endowment economy where the timing of market openings implies that only high-income agents hold money. Algan and Ragot (2010) study the effect of inflation and credit constraints in an incomplete-market economy where money is introduced in the utility function. To my knowledge, none of these papers is able to reproduce a realistic distribution of money. ${ }^{3}$ More recently, Telyukova (2011) uses a heterogeneous-agent model to account for the credit card puzzle, whereby a sizeable number of households report at the same time costly credit card debt and low-return liquid assets. She shows that introducing a stochastic need to pay in cash generates a precautionary demand for money, which can account for a large part of the puzzle. Introducing the stochastic cash-in-advance constraint in my model, one still finds that a sizeable participation cost in the financial market is necessary to account for the high inequality in money holdings.

The paper is organized as follows. Section 2 presents empirical facts about the distribution of money in Italy and the US. Section 3 shows that the usual assumptions regarding money demand fail to reproduce these facts. Section 4 describes the fixed transaction-cost model, and the parameterization appears in Section 5. Sections 6 and 7 present the results. Finally, Section 8 concludes.

\section{The distribution of money}

This section presents some empirical facts about the distribution of money and assets in Italy and the US. Although the model below is calibrated using US data, Italian data are used to check that the properties of the distribution of money are similar across countries. In the following, a narrow definition of money, M1, is used to emphasize the distinction between money and other financial assets. The robust stylized fact is that the distribution of money is similar to the distribution of assets. The same analysis has been carried out for various monetary aggregates and the results are quantitatively similar. As a summary of the following analysis, Fig. 1 depicts the Lorenz curves of the money, income and net worth ${ }^{4}$ distributions using the 2004 Survey of Consumer Finance, and those of the consumption, income, net worth, and money distributions using Italian data from the 2004 Survey of Households' Income and Wealth. In both cases, households whose head is aged between 35 and 44 are considered to avoid life-cycle effects. Money is more unequally distributed than income and net wealth in both countries.

\subsection{Italian data}

This section uses the 2004 Italian Survey of Households' Income and Wealth to examine the distribution of money. This periodic survey provides data for various deposit accounts, currency, income and wealth in the Italian population. Each survey is conducted on a sample of about 8000 households, and provides representative weights. A number of recent papers have used this data set to analyze money demand at the household level (Attanasio et al., 2002; Alvarez and Lippi, 2009, amongst others).

The top part of Table 1 shows the Gini coefficient of the distributions of consumption expenditures, income, net worth and money (in columns) for three different types of Italian households (in rows). The first column presents the Gini coefficient for total actual consumption expenditures. As one should consider the actual payments for each households, the total value of consumption expenditures is used..$^{5}$ The first row shows the figure for the whole population. This is fairly low, at .30. To avoid life-cycle effects the second line focuses on households whose head is aged between 35 and 44 . The Gini coefficient is almost unchanged at .29. The second column shows the results for the distribution of income. The Gini coefficient is a little higher than that of consumption at .35, falling to .32 for the 35-44 age group. The third column performs the same exercise for the distribution of net wealth. This is more dispersed than consumption or income: the Gini coefficient for net worth is .59 , increasing slightly to .61 for the $35-44$ age group.

Italian data are used to construct the quantity of money (M1) held by each household, as the sum of the amount held in currency and checking accounts. Although checking accounts are interest-bearing in Italy, the interest rate is low enough for this aggregation to be relevant: the average interest rate on checking accounts is below $1 \%$, whereas the average yearly yield of Italian 10-year securities was over 4\% in 2004. The last column of Table 1 shows the distribution of money. The Gini coefficient is very high here, at .68, and increases to .70 for the $35-44$ age group. As a robustness check, the distribution of

\footnotetext{
2 As Heathcote et al. (2009) note, the heterogeneous-agent literature has largely bypassed monetary economics, except for the few papers listed below

${ }^{3}$ Recent papers in the search-theoretic literature (for example, Chiu and Molico, 2010) also consider the inequality in money holdings. At this stage, these papers do not have a realistic financial market environment. The distribution of wealth is thus not consistent with the data.

${ }^{4}$ As is fairly usual, I use net worth as a summary statistic for all types of assets. The Lorenz curve of financial assets is very similar to that of net wealth.

${ }^{5}$ I have thus to depart from the literature which considers consumption inequality to relate it with income inequality. This literature defines a notion of consumption, which includes the imputed services from durable goods (See Krueger and Perri, 2006 or Bee et al., forthcoming for a recent example). This measure is relevant for normative purpose, but not to measure the actual expenditures by households.
} 

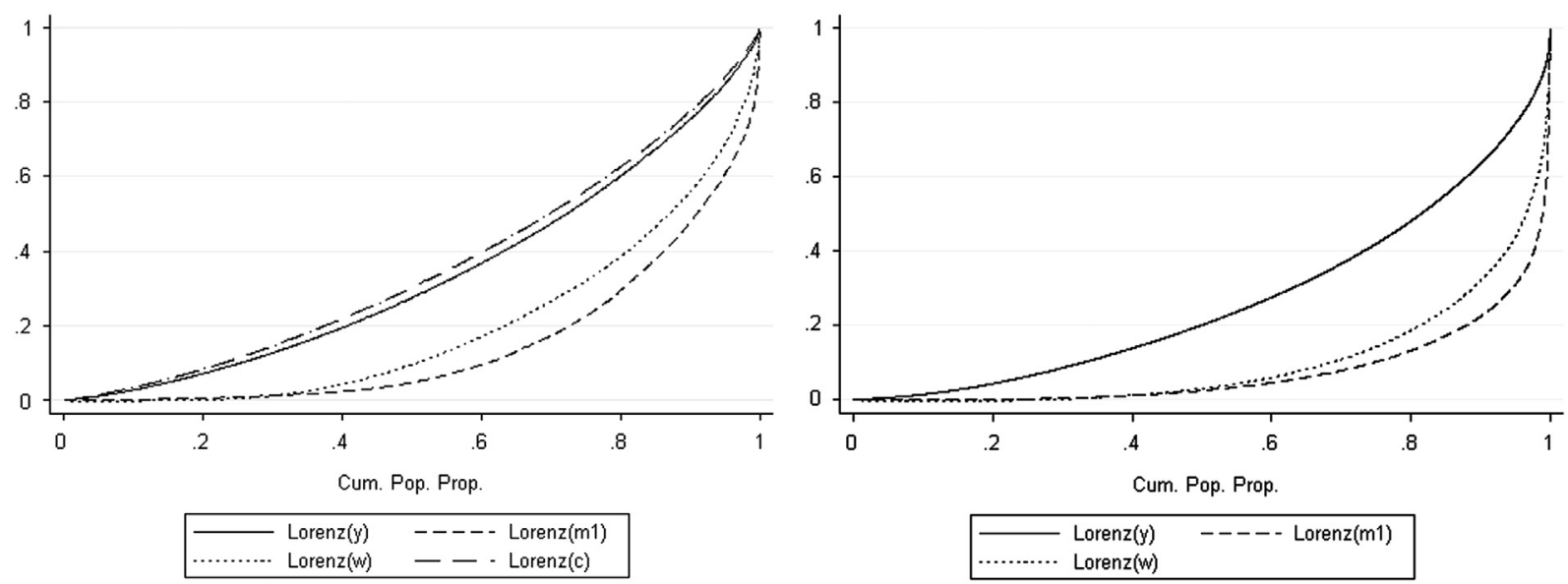

Fig. 1. Lorenz curves of income (y), Money (m1), Wealth (w) and Consumption (c), in Italy (left) and the US (right), for households whose head is aged between 35 and 44 .

Table 1

Distribution of money and wealth for Italy and the US, 2004.

\begin{tabular}{|c|c|c|c|c|}
\hline Gini coefficient of & Cons. & Income & Net $W$. & Money \\
\hline \multicolumn{5}{|l|}{ Italian data } \\
\hline Total Population & .30 & .35 & .59 & .68 \\
\hline Pop., $35 \leq$ Age $\leq 44$ & .29 & .32 & .61 & .70 \\
\hline Pop., $35 \leq$ Age $\leq 44,95 \%$ & .29 & .32 & .61 & .61 \\
\hline Gini coefficient of & Income & Net. W & Check. Acc. & Trans.Acc. \\
\hline \multicolumn{5}{|l|}{ US data } \\
\hline Total Population & .54 & .81 & .81 & .85 \\
\hline Pop., $35 \leq$ Age $\leq 44$ & .47 & .80 & .83 & .85 \\
\hline Pop., $35 \leq$ Age $\leq 44,95 \%$ & .45 & .77 & .66 & .81 \\
\hline
\end{tabular}

Note: Italian data are computed from the SHIW 2004. The definition of money is currency plus checking account for Italy. US data are computed from SCF, 2004.

money without including large money holders, who are defined as the top 5\% of the households who hold the most money, is also studied. ${ }^{6}$ The Gini coefficient on money holdings falls from .70 to .61 after this exclusion, thus remaining high.

The distribution of money is thus similar to that of net wealth, and is very different from that of consumption. For space reasons, this section has characterized the distribution by the Gini coefficient. However, other measures of inequality yield the same results. This can be seen graphically in Fig. 1, which shows the four Lorenz curves for the population aged between 35 and 44 .

The empirical correlations between money holdings, consumption levels, income and wealth can be calculated for Italian households between 35 and 44 years old. Money is positively correlated with consumption with a coefficient of .27, and positively correlated with net wealth with a coefficient of .30. In other words, households who consume more or who are richer hold more money. The correlation between wealth and the ratio of money over total financial assets is negative and equal to -0.13 . That is, the share of money in the financial portfolio falls with wealth. This property of the money/wealth distribution had already been noted in the US economy by Erosa and Ventura (2002).

\subsection{US data}

US data do not allow us to carry out the same detailed analysis: income, money and financial wealth come from the Survey of Consumer Finance (SCF), and the distribution of consumption can be found in the survey of Consumer Expenditures (CE). Hence, the correlation between consumption and money cannot be calculated. A conservative definition of money is used, which is the amount held in checking accounts. This is the only fraction of M1 which is available in the data. Statistics for the amount held in all transaction accounts, which corresponds roughly to the M2 aggregate, are also provided.

\footnotetext{
${ }^{6}$ I carry out this exercise even though it is problematic to justify the exclusion of this $5 \%$ of households. If households keep money to buy a house over a period of 1 week, and buy a new house as often as every 5 years, the probability that they will be observed with this money the day of the interview is only $(1 / 52) *(1 / 5)=.4 \%$.
} 
Table 2

Money distribution.

\begin{tabular}{lccccc}
\hline US, 2004, $35 \leq$ Age $\leq 44$ & & & & \\
\hline Fract. of pop. (\%) & 40 & 60 & 80 & 90 & 95 \\
Fract. of checking (\%) & .9 & 3.6 & 12.2 & 21.1 & 30.8 \\
\hline
\end{tabular}

Note: The table shows the fraction of total money holdings held by a given fraction of households in the money distribution. For example, the poorest $60 \%$ of the households in terms of money holds $3.6 \%$ of the money held by all households.

Summary statistics for US households are provided in the bottom part of Table 1, using the SCF 2004. ${ }^{7}$ The distribution of income is given in the first column. The Gini coefficient is .54 and decreases to .47 (second row) if the households whose head is aged between 35 and 44 are considered. It decreases further to .45 if one excludes the $5 \%$ money-richest households (third row).

The results for the distribution of net wealth are given in column 2. The values of the Gini coefficient are very similar between specifications, and range between .81 and .77 .

The Gini coefficient of the distribution of money held in checking accounts is given in column 3: this is very high at .81. Excluding life-cycle effects in the second row, the Gini coefficient increases to .83. This second row represents households between 35 and 44, which will be our reference group in the quantitative exercise. Finally the third row excludes the 5\% money-richest households: the Gini coefficient falls, but is still high at .66. The fourth column performs the same analysis for money held in all transaction accounts, such as checking, savings and money market accounts (M2 aggregate). The Gini coefficient here is of the same order of magnitude, and falls from .85 to .81. As a result, the distribution of money is closer to the distribution of net wealth than to the distribution of income.

The distribution of consumption expenditures can be obtained from the survey of Consumer Expenditures (CE). As for Italian data, the Gini coefficient is calculated for total consumption expenditures. Using the NBER extract of the Consumer Expenditures survey in 2002, one finds a Gini coefficient of .34. There is substantial empirical debate about the quality of the data (Attanasio et al., 2004). The consensus view however is that consumption expenditures are less unequally distributed than income. As a result, the distribution of money is much closer to the distribution of total wealth than to the distribution of consumption expenditures.

The correlation between money (checking account) and other assets can be calculated from the SCF. Money is positively correlated with net wealth (with a coefficient of .17): richer households hold more money on an average. The correlation between the ratio of money in financial wealth and total net wealth is negative (at -0.08). As in the Italian data, richer households hold more money but as a smaller fraction of their financial wealth.

Table 2 summarizes the distribution of money in the US in 2004, for the relevant age group. The first line gives the fraction of the population which holds the least money, the second line gives the fraction of total money held by this group of people. For instance, the $60 \%$ of the population who hold the least money hold $3.6 \%$ of the total of money in checking accounts. This table shows that the money is very unequally distributed, as the top $5 \%$ of the money distribution holds $69.2 \%$ of the amount held in checking accounts. This empirical distribution will be used to assess the ability of the model to reproduce the empirical money distribution. Moreover, considering this age group, one finds that households hold $8 \%$ of their income in money on an average. This ratio will be used to calibrate the model.

\subsection{Characteristics of large money holders}

Table 3 first compares the characteristics of large money holders, which are defined as the top $5 \%$ of the US money distribution, to the average in the US population (compare columns 1 and 2). The first line of Table 3 reports average money balances, and the second average net worth. The average money balance of households in the top $5 \%$ was $\$ 58,000$ in 2004 , whereas the sample average money balance is only $\$ 5012$. The ratio of money to net worth is $2.4 \%$ for households in the top $5 \%$, but only $1.1 \%$ on an average over the population. Large money holders thus have a greater share of money in their portfolio than does the average household. Large money holders tend to be older than the average household (58 and 50 years old respectively). They are also more likely to be self-employed: $29 \%$ as opposed to only $12 \%$ in the population. They are more educated (59\% have a college degree, compared to $37 \%$ on an average), more likely to own a house (92\% home ownership, compared to $69 \%$ ), and more likely to hold stock $^{8}$ (49\% compared to $20 \%$ ).

Table 3 also investigates the properties of large money holders by comparing them to rich households, defined as the top $5 \%$ in the wealth distribution (see columns 2 and 3). Rich households hold money equal to $0.6 \%$ of their net worth, which is lower than the fraction of money held on an average (1.1\%). Rich households are more likely to be self-employed (41\%

\footnotetext{
${ }^{7}$ The high value of the inequality of money holdings does not depend on the year of the survey. The Gini coefficient for checking accounts is .74 in the 2001 SCF survey and .72 in the 1998 SCF survey. Note that the nominal interest rate (Fed's fund rate) was above 5\% on an average and the opportunity cost of holding this liquidity was considerable over this period.

${ }^{8}$ I consider stock holders as households who report positive levels of directly held stock.
} 
Table 3

Characteristics of large money holders.

\begin{tabular}{llll}
\hline & Tot.pop. & Top 5\% (money) & Top 5\% (wealth) \\
\hline Average money balances & 5012 & 58,000 & 32,600 \\
Average net worth & 448,000 & $2,348,000$ & $5,156,500$ \\
Age & 50 & 58 & 59 \\
Fract. self-employed (\%) & 12 & 29 & 41 \\
Fract. college (\%) & 37 & 59 & 80 \\
Fract. home owner (\%) & 69 & 92 & 97 \\
Fract. stock holder (\%) & 20 & 49 & 69 \\
\hline
\end{tabular}

Note: The table shows the characteristics (in rows) of US households (column 2), of the top $5 \%$ of households in the money distribution (column 3 ) and of the top $5 \%$ of households in the wealth distribution (column 4).

compared to $29 \%$ ), more educated ( $80 \%$ of households having a college degree, as compared to 59\%), and hold more stocks (69\% compared to $49 \%$ of direct stock owners) than large money holders.

This comparison reveals that large money holders are rich, but they are less educated and less likely to directly hold stock than are rich households. These findings can help motivate the interpretation of the portfolio-adjustment cost as an information-processing cost, which is likely to be higher for less-educated households.

To summarize these US and Italian findings: (1) inequality in money holdings is more similar to inequality in net wealth and very different from inequality in consumption; (2) money is positively correlated with wealth and consumption; and (3) the ratio of money over wealth falls with wealth.

\section{Difficulties in linking money and consumption}

Simple models of money demand cannot reproduce the shape of the distribution of money when they link money demand to consumption. These models assume that the real money holdings of a household $i, m^{i}$, are simply proportional to consumption, $c^{i}$

$$
m^{i}=A c^{i}
$$

where $A$ is a scaling factor, the same for all households, which may depend on the nominal interest rate, real wages and preference parameters. This form is used for instance in Cooley and Hansen (1989) to assess the welfare cost of inflation. It also results in all models with money-in-the utility function (MIUF) where the utility function is homothetic in money and consumption in the sense of Chari et al. (1996), which is the benchmark case in this literature. It is also obtained in a simple specification of the shopping-time model (McCallum and Goodfriend, 1987). In this case, the distributions of money and consumption are homothetic, and their Gini coefficients are equal. This is at odd with the data, as shown in Section 2.

\subsection{Economies of scale in the transaction technology}

Some authors have noted that the share of money holdings in total wealth falls with total wealth, and have concluded that the transaction technology exhibits scale economies: richer households, even if they consume more, need less money because they buy more goods via credit. Dotsey and Ireland (1996) provide a microfoundation of this transaction technology, which uses the flexibility provided by the definition of cash and credit goods in Stokey and Lucas (1987). Erosa and Ventura (2002) use this formulation in a heterogenous-agent setting. This implies that the quantity of money and the consumption level of household $i$ satisfy the following relationship:

$$
\frac{m^{i}}{c^{i}}=A\left(c^{i}\right)^{-\kappa} \quad \text { with } \kappa>0
$$

However, this specification is not able to reproduce a realistic distribution of money. With moderate returns (a low value of $\kappa$ ), the distribution of money is more equally distributed than the distribution of consumption, because households with higher consumption levels hold fewer real balances. A more dispersed distribution of money can only be obtained with implausibly high increasing returns in the transaction technology. In this case, households who consume the most hold almost no money, whereas households who consume little hold higher levels of money balances. However, one implication of this assumption is that consumption and money should be negatively correlated, as higher consumption implies lower money holdings and vice versa. This correlation is rejected by the data.

To illustrate, the distribution of consumption of Italian households aged between 35 and 44 is used to generate fictitious money distributions. These distributions are generated with various transaction technologies, using the general form of the transaction technology (2) for various values of $\theta$. The distributional properties of the joint distribution of money and consumption expenditures are then analyzed.

Table 4 presents the value of the Gini coefficient and the correlation between money and consumption for various values of $\kappa$. For $\kappa$ less than 1, the distribution of money is less concentrated (lower Gini coefficient) than the distribution of 
Properties of the distribution of money for different transaction technologies.

\begin{tabular}{lllll}
\hline Values of $\kappa$ & Data & 0 & 0.5 & 1 \\
\hline Gini of consumption & .29 & 29 & .29 & .29 \\
Gini of money & .70 & .29 & .29 & 0 \\
Corr. money consumpt. & .27 & 1 & .97 & .30 \\
\hline
\end{tabular}

Note: The table shows the Gini coefficient of money and the correlation between money and consumption, using the Italian distribution of consumption expenditures and generating a distribution of money for various transaction technologies $(\kappa)$.

consumption. To obtain a more concentrated distribution of money, the returns on the transaction technology must be greater than 1, but the correlation between money and consumption then becomes negative, which is at odds with the data.

The same type of experiment can be carried out with the US Data. A fictitious distribution of consumption can be generated with distribution of money using (2). The coefficient $\kappa$ is set to a value for which the distribution of consumption is realistic in terms of the Gini coefficient. Again, a value of $\kappa$ of over 3 is needed to obtain a Gini coefficient under .47 , which is the Gini coefficient on income.

Finally, note that the microfoundation of money demand with scale economies in Dotsey and Ireland (1996) requires increasing returns to scale to obtain the correct sign on the interest elasticity of money demand.

To sum up, economies of scale in the transaction technology cannot on their own generate a realistic distribution of money. This is because money is at the same time positively correlated with consumption expenditures and much more concentrated than consumption expenditures. The following model then proves that one can obtain a realistic distribution of money by focusing on transaction technologies in the financial market and not in the goods markets. The correlation between money and consumption will appear as an outcome, rather than as a specific utility function imposed on the households.

\subsection{Unobserved heterogeneity}

The discussion above made no reference to unobserved heterogeneity. However, the relationship between money demand and consumption could well take the form

$$
m^{i}=A^{i} c^{i}
$$

where any heterogeneity in $A^{i}$ could yield considerable inequality in money holdings. ${ }^{9}$ Nevertheless, explanations based on unobserved heterogeneity are not satisfactory as the degree of heterogeneity needed to match the data is considerable. Using Italian data, for which data on consumption are available, the Gini coefficient over the $A^{i}$ coefficients is .66, and is thus greater than the Gini coefficient on consumption or income. This value is so high because the correlation between money and consumption is low. As a result, the heterogeneity assumed is of the order of magnitude of the value to be explained. The strategy of this paper is to focus on a structural model to reproduce the distribution of money across households as an equilibrium outcome without assuming any unobserved heterogeneity.

\section{The model}

The economy is populated by a unit mass of infinitely lived households who consume a consumption-investment good. There are two assets: money and a riskless interest-bearing asset. There is no aggregate uncertainty, but households face idiosyncratic productivity shocks. These shocks are not insurable, and households can partially self-insure by holding money or riskless assets. Households must pay a fixed cost $\lambda$ in terms of the final good ${ }^{10}$ to enter the financial market in order to adjust their financial position, and pay no cost to adjust their monetary holdings. Moreover, households must hold money in order to consume according to a simple transaction technology.

\subsection{Households}

Households enjoy utility from consumption $c$ and disutility from hours worked $n$. Households' discount factor is denoted $\beta$. For simplicity only, I follow Greenwood et al. (1988), Domeij and Heathcote (2004) in assuming the following functional form for the period utility function (see also Heathcote, 2005, for a discussion of the properties of this functional form):

$$
u(c, n)=\frac{1}{1-\gamma}\left[\left(c-\psi \frac{n^{1+1 / \varepsilon}}{1+1 / \varepsilon}\right)^{1-\gamma}-1\right]
$$

\footnotetext{
${ }^{9}$ This reduced-form formulation can be obtained with a MIUF, a cash-in-advance or a shopping-time framework (see Feenstra, 1986; Croushore, 1993, for instance).

${ }^{10}$ The results do not significantly change if we assume that this cost is paid in labor, and thus affects labor supply.
} 
In this specification, $\varepsilon$ is the Frisch elasticity of labor supply, $\psi$ scales labor supply, and $\gamma$ measures the concavity of the utility function. ${ }^{11}$ In each period, a household $i$ can be in one of three states according to its labor market status. Its productivity $e^{i}$ is then either $e^{1}, e^{2}$ or $e^{3}$. For instance, a household whose productivity is $e^{1}$ which works $n$ hours earns labor income of $e^{1} n w$, where $w$ is the real wage by efficiency unit. Labor productivity $e^{i}$ follows a three-state first order Markov chain with a transition matrix denoted $T$. Given standard conditions, which will be fulfilled here, the transition Matrix $T$ has a unique ergodic set $N^{*}=N_{1}^{*}, N_{2}^{*}, N_{3}^{*}$ such that $N^{*} T=N^{*}$. To simplify the dynamics, it is assumed that the economy starts with the distribution $N^{*}$ of households.

Denote as $a$ and $m$ the real quantity of financial assets and real money holdings held by a given household, at the beginning of the current period. The values of these quantities held at the beginning of the next period are denoted as $a^{\prime}$ and $m^{\prime}$. Each period, the household has the choice to participate or not in financial markets. If she participates, she pays a fixed $^{12}$ cost $\lambda$ and can freely use her total monetary and financial resources. In this case, her budget constraint is

$$
m^{\prime}+a^{\prime}+c=e n w+\frac{m}{\Pi}+(1+r) a-\lambda,
$$

where enw is the labor income; $m / \Pi$ is the real value of money holdings in the current period, where $\Pi$ is the gross inflation rate between the previous and the current period; $(1+r) a$ is the return on the financial portfolio with a constant real interest rate $r$.

If the household does not participate, she cannot use her financial income to consume. In this case, it is assumed that her financial wealth is reinvested in financial assets ${ }^{13}: a^{\prime}=(1+r) a$. There are now two budget constraints

$$
\begin{aligned}
& m^{\prime}+c=e n w+\frac{m}{\Pi} \\
& a^{\prime}=a(1+r)
\end{aligned}
$$

In addition, households must hold cash before consuming. Following Lucas (1982) in assuming that financial markets and money markets open before the goods market. ${ }^{14}$ As a consequence, households face the following cash-in-advance constraint:

$$
\theta c \leq m^{\prime}
$$

where $\theta$ is a technology parameter which reflects the consumption velocity of money. Combining (6) and (8), one finds that $c \leq(e n w+m / \Pi) /(1+\theta)$. In words, when the agent does not participate in financial markets, he or she can consume up to a fraction $1 /(1+\theta)$ of his or her revenue, $e n w+m / \Pi$, due to the cash-in-advance constraint. The revenue which is not used to consume is kept in money.

There are two motives for holding money in this specification. First, money is necessary for consumption, due to the cash-in-advance constraint. This constraint summarizes the transaction role of money. Second, money can also be held for a "financial motive", which is to avoid the portfolio-adjustment cost in financial markets. Finally, no household can issue money $m^{\prime} \geq 0$, and households face a simple borrowing limit when participating in financial markets: $a^{\prime} \geq 0$.

\subsection{Recursive formulation}

The household's program can be written in a recursive way as follows (see Bai, 2005, for a proof of the existence of Bellman equations in this type of economy). Define $V^{p a r}(a, m, e)$ as the maximum utility that a household with productivity $e$ can reach in the current period, if she participates in financial markets and if she holds an amount $m$ and $a$ of monetary and financial wealth respectively; $V^{e x}(a, m, e)$ is the analogous utility if the household does not participate. The Bellman value $V^{\text {par }}(a, m, e)$ satisfies

$$
V^{p a r}(m, a, e)=\max _{a^{\prime}, m^{\prime}, n, c} u(c, n)+\beta E \max V^{p a r}\left(m^{\prime}, a^{\prime}, e^{\prime}\right), V^{e x}\left(m^{\prime}, a^{\prime}, e^{\prime}\right)
$$

\footnotetext{
11 The parameter $\gamma$ is related to the risk-aversion coefficient. For a discussion about how to measure risk aversion in models with labor supply, see Swanson (2012)

${ }^{12}$ I have also solved the model introducing costs of participating in financial markets which are proportional to the amount traded. For a realistic calibration, they did not quantitatively change the results. As a consequence, I do not consider them in the paper.

13 This is the standard assumption made by Romer (1986) for instance.

14 This timing convention is more convenient here than that in Svensson (1985). In this latter case, households must choose their money holdings one period before consuming. As a consequence, households would not be able to adjust their money holdings after their idiosyncratic productivity shock, to adjust their consumption within the period, but would be able to adjust their financial portfolio. This would create a discrepancy between money and financial assets, which is problematic for this paper's subject. Alternatively, this constraint could be introduced as a condition imposed by banks for households to keep some money on their account.

Two alternative foundations can be provided for this constraint in the heterogeneous agents framework. First agents are only allowed to spend a fraction $1 /(1+\theta)$ of their income immediately because the bank requires that they keep the remaining fraction in their account. Alternatively, following Lucas (1982) one can assume that there are cash goods and credit goods. They must be consumed in fixed proportions, and agents can only buy cash goods by producing and selling an equal amount of the cash good. The first assumption implies that spending on cash goods is proportional to total spending, the second implies money balances carried into the next period are proportional to spending on cash goods. These two setups yield the same reduced form.
} 
subject to the constraints (5), (8) and the positivity constraints $c, n, a^{\prime}, m^{\prime} \geq 0$. The expectation operator $E$ is taken over the idiosyncratic shock. The household maximizes its current utility anticipating that next period's participation decision will be made next period, after the next period idiosyncratic shock is revealed.

The value $V^{e x}(a, m, e)$ satisfies

$$
V^{e x}(m, a, e)=\max _{m^{\prime}, n, c} u(c, n)+\beta E \max V^{p a r}\left(m^{\prime}, a^{\prime}, e^{\prime}\right), V^{e x}\left(m^{\prime}, a^{\prime}, e^{\prime}\right)
$$

subject to the constraints (6), (7), (8) and the positivity constraints $c, n, m^{\prime} \geq 0$. When not participating in financial markets, the next period financial asset is not a choice variable, but the household anticipates that he or she will be willing to participate or not the next period.

Finally, the maximum utility that a household with productivity $e$ and assets $m$ and $a$ can attain is

$$
V(m, a, e)=\max V^{p a r}(m, a, e), V^{e x}(m, a, e)
$$

According to this last maximization, the household either chooses to participate or not.

Solving for the households problem, one can find the optimal decision rule. ${ }^{15}$ Then, as is standard in this literature, the steady distribution of financial wealth, money and productivity level is the invariant distribution for the households' decision rules and the transition matrix $T$.

\section{Parameterization}

The model period is one quarter. Table 5 summarizes the parameter values at a quarterly frequency in the benchmark equilibrium.

\subsection{Preference parameters}

The preference and technology parameters have been set to standard values. The discount factor $\beta$ is set to .9875, to obtain a realistic average wealth over income of 3. The risk-aversion parameter, $\sigma$, is set to 1.5. The Frisch Elasticity of labor supply $\varepsilon$ is estimated to be between 0.1 and 1 . A conservative value of .3 is used. Given this value, $\psi$ is set such that aggregate effective labor supply is close to .33 .

The household productivity process: Different models of the income process are now used in the literature. In this paper, the process in Domeij and Heathcote (2004) is used. This process is designed to generate both realistic cross-sectional wealth inequality and realistic persistence and variance in household income dynamics. An additional important advantage of this process is that it generates a realistic distribution of consumption expenditures across households. These three properties are potentially important for the question of the shape of the money distribution.

Domeij and Heathcote estimate a three-state Markov process, which reproduces the process for logged labor earnings using PSID data. The Markov chain is estimated under two constraints: (i) the first-order autocorrelation in annual labor income is .9; and (ii) the standard deviation of the residual in the wage equation is .224. These values are consistent with estimations found in the literature (Storesletten et al., 2007, amongst others).

The transition matrix is symmetric and is

$$
T=\left[\begin{array}{ccc}
.974 & .026 & 0 \\
.0013 & .9974 & .0013 \\
0 & .026 & .974
\end{array}\right]
$$

The three productivity levels are $e^{1}=4.74, e^{2}=.848, e^{3}=.17$. The long-run distribution of productivity across the three states is $N^{*}=[.045 .91 .045]^{\prime}$. This process introduces considerable inequality in earnings, which generates inequality in the wealth distribution.

\subsection{Real interest rate, real wage and monetary parameters}

The household's portfolio choice is between two riskless assets with different returns and different portfolio adjustment cost. The equity premium is thus outside the scope of my paper, as there is no aggregate risk here. To be consistent with the model, the return on the financial asset is set equal to the real return on riskless bonds. The interest rate thus is .37\%, which is the quarterly real interest rate on 10 years treasury in 2004 . The real wage is $w=1.70$, which is the value given by a standard price factor frontier. ${ }^{16}$

The other parameters concern monetary policy and the transaction cost. First, the 2004 US annual inflation rate was $2.8 \%$. Consequently, the quarterly inflation rate is $\pi=.7 \%$. The remaining parameters concern the portfolio adjustment cost $\lambda$ and the transaction constraint coefficient $\theta$.

\footnotetext{
15 The computational strategy is provided in the online Appendix.

${ }^{16}$ More precisely, this real wage is obtained with a production function which has a Cobb-Douglas technology with constant depreciation rate. The capital share is 0.36 and the annual depreciation rate is $6 \%$.
} 
Table 5

Parameter values.

\begin{tabular}{lllllllll}
\hline$\beta$ & $\sigma$ & $\varepsilon$ & $\psi$ & $w$ & $r$ & $\pi$ & & \\
\hline .9875 & 1.5 & .3 & 175 & 1.70 & $.37 \%$ & .09 \\
\hline
\end{tabular}

Note: $\beta$ is the discount factor; $\sigma$ is the curvature of the utility function; $\varepsilon$ is the Frisch elasticity of labor supply $\psi$ scales labor supply; $w$ and $r$ are the real wage and interest rate, respectively; $\pi$ is the quarterly inflation rate; $\lambda$ is the financial participation cost; $\theta$ is the value of the transaction constraint on the goods market.

These two parameters are chosen to match two targets. The first one is the ratio of aggregate money over aggregate income. The second one is the quantity of money held by the bottom $40 \%$ of the money distribution. Money is defined as above as the amount in checking accounts in SCF 2004. The ratio of money over annual income is 8\% for households between 35 and 44 years old. The bottom $40 \%$ of the money distribution hold $.9 \%$ of the total money stock. One finds a value of the participation cost equal to $\lambda=.09$ and a transaction constraint $\theta=.015$. To summarize the results analyzed in detail below, a large $\lambda$ is necessary to obtain considerable inequality in money holdings. A low but positive transaction parameters $\theta$ is necessary to reproduce the money holdings of the poorest households. Various sensitivity analyses are provided below. Scaling by average annual household income in the US of $\$ 43,000$, one finds an annual transaction cost in financial markets for the riskless asset of around \$725. To my knowledge, there is no consensus in the empirical literature regarding the level of such costs. The empirical strategy of Mulligan and Sala-i-Martin (2000) and Paiella (2001) only provides the median cost or the lower bound of the participation cost. Some insights can be obtained from the literature which estimates the cost of participating in the risky-asset market. Vissing-Jorgensen (2002) estimates that the per period median participation cost is $\$ 350$ in 1984, but the per period participation cost must be as high as $\$ 1000$ to explain the participation decision of $70 \%$ of the population. Moreover, Kaplan and Violante (2011) consider the same type of model for the analysis of fiscal policy and find that a range of \$500-\$1000 is necessary to obtain a realistic portfolio for private agents, which is consistent with my findings.

\section{Household behavior in the benchmark model}

First, the inequality in money holdings does not come from inequality between households according to their productivity. High-productivity households (type-1 households) represent $4.5 \%$ of the population and hold $26.3 \%$ of the money stock. Households with medium productivity (type-2 household) hold 68.5\% of the money stock and represent $91 \%$ of the population. Finally, low-productivity households (type-3) are $4.5 \%$ of the population and hold $5.2 \%$ of the money stock, which is a higher proportion than their share of the population. The inequality in money holdings will thus come from the heterogeneity within types of households.

To provide a better understanding of the sources of inequality in money holdings, Fig. 2 depicts the evolution in the saving behavior in money and financial assets of an agent who is always of type 1, 2 or 3 , with the same initial portfolio composed of 1 unit of financial assets and no money. Note that, in this exercise, the household's productivity does not change whereas some change is expected to occur from the transition matrix $T$. As a consequence, these figures should be read as particular household histories.

In Fig. 2, one can observe that type-1 households often go (every two periods) to financial markets. This yields a rapid accumulation of financial assets: these households save and accumulate a high buffer stock.

The portfolio choice of a type-2 household is also shown in Fig. 2. When a threshold for financial assets is reached, the household participates in financial markets. In this case, it replenishes money holdings by selling financial assets. This buffer stock is quickly reduced to a small amount consistent with the transaction constraint on the goods market, after 3 periods. The opportunity cost of holding money is very high, as its return is negative.

A type-3 household decumulates all financial wealth down to 0 in one period. He or she first transfers a part of their wealth to money at the second period and then holds just a little amount of money which is necessary in order to consume, because of the transaction constraint on the goods market. These agents thus hold only a little amount of money after a very short period.

In conclusion, households participate infrequently in financial markets, which creates inequality in money holdings across households. Moreover, more productive households often hold more money than do less productive ones, but this ranking is not constant and depends on household wealth. This will explain the correlation between money and wealth described in the next section. The results of the model for the benchmark parameters and for alternative economies are now presented. The frictions on the goods and financial markets are successively removed. This exercise will allow quantifying the contribution of each motive to total money holdings.

\section{The distribution of money and financial assets}

The distribution of wealth and money is summarized in Table 6. The table provides the Gini coefficient for consumption, money and wealth and the shape of the money distribution in various economies. Columns 2 and 3 show the value of money parameters, whereas the first column labels the economies from 1 to 5 . 

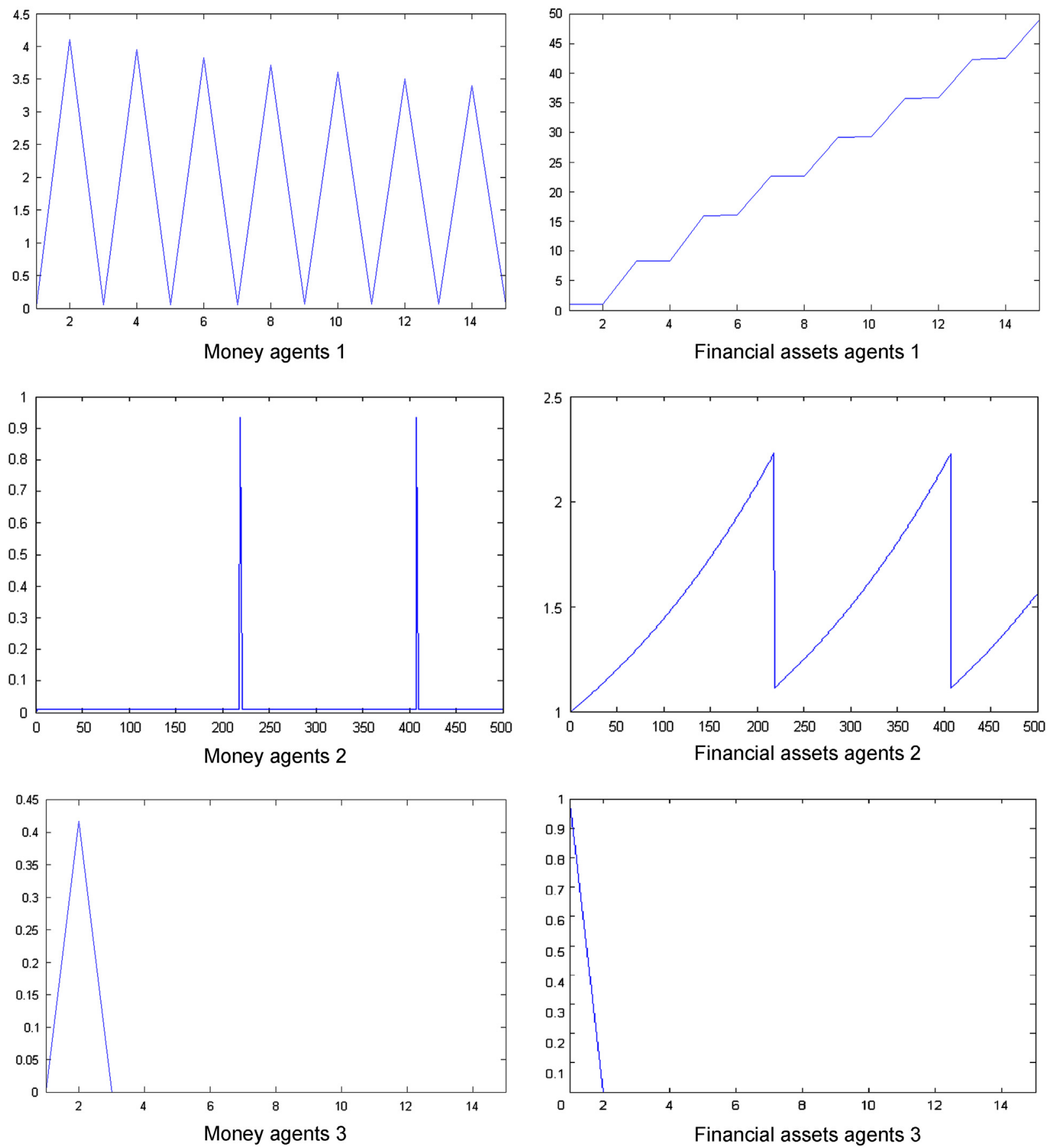

Fig. 2. The evolution of money and financial assets of households with different productivity levels. The $x$-axis is the number of periods. The $y$-axis is the real value of money or of financial assets held by households.

\subsection{Benchmark economy}

Economy 1 is the benchmark economy. The model performs quantitatively well in reproducing the inequality of the distributions of consumption, money and wealth. The Gini of the total wealth distribution is .87. The Gini coefficient for money is .80 , which is similar to that actually observed in the US economy (.83), and the Gini coefficient for consumption expenditures is close to its empirical counterpart (.29 compared to .34.). The other columns show the money held by different fractions of the population. As targeted, the bottom $40 \%$ of the money distribution in the model holds the same amount as the empirical counterpart, $0.9 \%$ of the money stock. The bottom $80 \%$ of the money distribution holds $14.9 \%$ of the money stock, which is close to the empirical counterpart (12.2\%). Although the model is able to reproduce the considerable 
Table 6

Inequality measures and distribution of money.

\begin{tabular}{|c|c|c|c|c|c|c|c|c|c|c|}
\hline \multicolumn{3}{|c|}{ Data and model economies } & \multicolumn{3}{|c|}{ Gini coefficient of } & \multicolumn{5}{|c|}{ Distribution of money (in \%) } \\
\hline & & & Consn. & Money & Wealth & $40 \%$ & $60 \%$ & $80 \%$ & $90 \%$ & $95 \%$ \\
\hline \multicolumn{11}{|l|}{ Model } \\
\hline 1. & 9 & 1.5 & .29 & .80 & .87 & .9 & 1.6 & 14.9 & 33.8 & 55.6 \\
\hline 2. & 0 & 1.5 & .30 & .30 & .84 & 23 & 31 & 53 & 65 & 76 \\
\hline 3. & 9 & 0 & .29 & .89 & .87 & 0 & 0 & 0 & 17.6 & 44.6 \\
\hline 4. & 5.6 & 3 & .30 & .68 & .87 & 1.7 & 5.1 & 27.3 & 46.2 & 62 \\
\hline 5. & 8.3 & $\{.75,2.25\}$ & .30 & .80 & .86 & .5 & 1.57 & 15.2 & 35.4 & 57.3 \\
\hline
\end{tabular}

Note: The table shows the Gini coefficients for the distribution of consumption expenditures, money and wealth and the shape of the money distribution in five different economies. Monetary parameters are given in columns 2 and 3.

inequality in money holdings, and thus the high Gini coefficients, it does not fully capture the empirical inequality in money holdings at the top of the distribution. ${ }^{17}$ For instance, the bottom $95 \%$ of the money distribution holds $55.6 \%$ of the money stock in the model but only $30.8 \%$ in the data.

The correlation between money and wealth generated by the model is .37, which has the same sign as the correlation found in the data for the relevant age group, which is .17. The model also generates a negative correlation between wealth and the ratio of money to total wealth, of -0.28 ; the corresponding value in the data is -0.08 .

\subsection{The role of transaction and participation constraints}

Economy 2 is that where agents do not face any participation costs in financial markets but a transaction constraint on the goods market. In this case, the Gini coefficient of money is too low (.3) compared to that in the data (.8). The money distribution presented in columns 7-11 shows that the bottom part of the distribution holds too much money. This is the result discussed in Section 3.

Economy 3 is that where agents face the participation cost for financial markets but no transaction constraints on the goods market. The model is able to reproduce realistic levels of inequality for consumption, money and wealth, as measured by the Gini coefficients. For instance, the Gini coefficient for the money distribution is as high as .89. Nevertheless, the underlying shape of the money distribution is unrealistic. The bottom $80 \%$ of the money distribution does not hold any money in the model, whereas they hold $12.2 \%$ of the money stock in the data. In this economy, households hold money for only a few periods after participating in financial markets, because the opportunity cost of holding money is high. They thus rapidly drive their money balances down to zero. Only few households hold large quantities of money, which explains the high level of inequality in money holdings. However, in consequence, too many households do not hold any money.

\subsection{Alternative parameter values}

Economy 4 provides an alternative calibration which yields roughly the same capital and money stocks. In this calibration, the transaction motive has been increased from $1.5 \%$ to $3 \%$ and the participation cost in financial markets has been cut from $9 \%$ to $5.6 \%$ to produce the same ratio of money over income. In this calibration, this discount factor is reduced from .9875 to .9872 to provide the same ratio of financial wealth over income. First, this alternative calibration provides inequality figures for consumption and financial wealth which are close to those obtained in the benchmark calibration, but the inequality in money holdings is smaller than that in the data: the Gini coefficient for money is now .68. In this economy, the transaction constraint has more weight than the effect of the participation cost. As a consequence, the bottom part of the money distribution holds too much money compared to the data.

\subsection{Uncertainty in the transaction constraint}

Uncertainty in the transaction constraint is now introduced. Telyukova and Wright (2008) show that a time-varying transaction constraint generates precautionary saving to hold money, which can explain the demand for money for households having some credit card debt. Time-varying transaction constraints are introduced not to underestimate the role of frictions on the goods market. Households now face the cash-in-advance constraint

$$
\theta c \leq m^{\prime} \quad \text { where } \theta \in \theta^{h}, \theta^{l}
$$

where $\theta$ is now a i.i.d. stochastic variable, which can take the two values $\theta^{h}$ or $\theta^{l}$, both with probability of $1 / 2$. When $\theta^{i}$ is high, households want to consume more cash-goods and thus need more money. The foundation for a varying $\theta^{i}$ is thus preference

\footnotetext{
${ }^{17}$ The difficulty in fully capturing inequality at the top of the distribution is well known in this class of models (see De Nardi, 2004, for instance).
} 
Table 7

Quantification of money demand motives.

\begin{tabular}{ll}
\hline Economies & Money/income (\%) \\
\hline$\lambda=9 \% ; \theta=1.5 \%$ & 8 \\
$\lambda=9 \% ; \theta=0$ & 6.25 \\
$\lambda=0 ; \theta=1.5 \%$ & .33 \\
\hline
\end{tabular}

Note: The table shows the ratio of total money stock over total income for three different economies with and without transaction and participation costs.

shocks in terms of the utility of cash-goods. To solve the households' problem, one must solve for the value functions $V^{e x}(m, a, e, \theta)$ and $V^{e x}(m, a, e, \theta)$, which are defined as in (9) and (10), except that the cash-in-advance constraint is (12) instead of (8).

The results are provided in the Economy 5. The transaction coefficient equals .0075 with probability $1 / 2$ and .0225 with probability $1 / 2$. As a result, the average expected value of the coefficient is 1.5 , which is the value chosen in the benchmark economy. These values are chosen (1) to obtain a realistic Gini coefficient over money, and (2) to obtain realistic uncertainty in the transaction constraint on the goods market. The choice of an i.i.d. process is done to maximize the conditional variance on next period cash-in-advance, not to underestimate the effects. Introducing autocorrelation would indeed reduce the effects. Introducing various controls, Telyukova (2011) finds that the variance of the unpredictable part of households' cash-good log consumption is around .06. To obtain this variance, if households consume an average of 1.5 units of cashgoods, they have to consume .0075 with probability of $1 / 2$ and .0225 with probability $1 / 2$. To obtain a realistic amount of money in the economy, one has to reduce the participation cost from $9 \%$ in the benchmark economy to $8.3 \%$.

Although uncertainty allows the participation cost to fall, the high Gini coefficient is obtained at a cost of too little money held by money-poor agents: the bottom $40 \%$ of the money distribution holds . $5 \%$ of the money stock, almost half the amount observed in the data and in the benchmark model (.9\%). As a consequence, although uncertainty in the amount of cashgoods to be consumed is important for the explanation of money demand by some agents, it does not help to explain the considerable inequality in the money distribution across households.

\subsection{A quantification of money demand motives}

A quantification of the contribution of each friction to money demand can now be provided. One can compare the quantity of money obtained in three different economies: the benchmark economy, the economy with frictions on the goods market only, and the economy with frictions on the financial market only.

The results are summarized in Table 7 . The first line is the benchmark economy where both frictions are introduced: $\lambda=9 \% ; \theta=.015$. The second column provides the value of the annualized quantity of money over households' total income: this equals $8 \%$, which is the targeted value.

The second line is the economy with financial motives, where frictions on the goods market are absent, $\theta=0$. One finds a quantity of money equal to $6.25 \%$ of total income, corresponding to $78 \%$ of the quantity of money obtained in the benchmark economy. This comparison thus shows that frictions on the goods market explain $22 \%$ of total money demand.

The third line is the economy with the friction on the goods market only: $\lambda=0$. The quantity of money falls to a value of $.33 \%$. The real quantity of money obtained in this economy corresponds to only $4.1 \%$ of the quantity of money obtained in the benchmark economy. This experiment then leads us to conclude that financial frictions represent roughly $95 \%$ of total money demand in the benchmark economy.

An additional insight from these comparisons is that both frictions interact in a non-linear way. The money obtained when both frictions are introduced is greater than the sum of the quantity of money for each friction. Households which go only infrequently to financial markets have to hold a higher quantity of money when there is friction on the goods market, because they now have to hold more money to be sure of fulfilling the cash-in-advance constraint in future periods.

Comparing these three economies, one can conclude that the amount of money demanded via the financial motive represents over $78 \%$ of the total quantity of money. One could already have anticipated this result in Section 2 , where the empirical money distributions were presented: a considerable departure from the transaction motive on the goods market is necessary for the reproduction of both a great deal of inequality in money holdings and little inequality in consumption.

\section{Conclusion}

The distribution of money across households is similar to the distribution of financial assets, and very different from the distribution of consumption. This fact appears as a puzzle for theories of money demand which directly link money demand and consumption. The contribution of this paper is to show that the distribution of money can be reproduced as an equilibrium outcome when a transaction friction is introduced on both the goods and financial markets. The friction on the goods market is a standard cash-in-advance constraint, while the friction on financial markets is a portfolio adjustment, as in the Baumol-Tobin literature. Considering each friction successively, it is found that the financial friction alone explains 
$78 \%$ of the quantity of money in circulation. A path for future research would be to search for a simple shortcut to introduce a financial friction generating money demand in macroeconomic models.

\section{Acknowledgments}

I have benefited from helpful comments from Yann Algan, Fernando Alvarez, Gadi Barlevy, Marco Bassetto, Jeff Campbell, Edouard Challe, Andrew Clark, Mariacristina DeNardi, Jonas Fisher, Per Krusell, François Le Grand, Francesco Lippi, Dimitris Mavridis, Frédéric Lambert, Benoit Mojon, Monika Piazzesi, Vincenzo Quadrini and François Velde. I also thank seminar participants at the Banque de France, the Federal Reserve Bank of Chicago, the Riksbank, CEF 2008, ESEM 2008, the CEPR 2009 ESSIM, the SED 2009 conferences and the "2010 Consumer Payment Choice" Workshop in Vienna. This paper has benefited from support from the French ANR, No. JCJC0157.

\section{Appendix A. Supplementary material}

Supplementary data associated with this article can be found in the online version at http://dx.doi.org/10.1016/j.jmoneco. 2013.09.005.

\section{References}

Algan, Y., Ragot, X., 2010. Monetary policy with heterogenous agents and borrowing constraints. Review of Economic Dynamics 13, 295-316. Akyol, A., 2004. Optimal monetary policy in an economy with incomplete markets and idiosyncratic risk. Journal of Monetary Economics 51, 1245-1269. Alvarez, F., Atkeson, A., Kehoe, P., 2002. Money, interest rates, and exchange rates with endogenously segmented markets. Journal of Political Economy $110,73-112$. Alvarez, F., Lippi, F., 2009. Financial innovation and the transactions demand for cash. Econometrica 77, 363-402.

Attanasio, O., Guiso, L., Jappelli, T., 2002. The demand for money, financial innovation and the welfare cost of inflation: an analysis with household data. Journal of Political Economy 110, 317-351.

Attanasio, O., Battistin, E., Ichimura, H., 2004. What Really Happened to Consumption Inequality in the US?. NBER Working Paper 10228.

Bai, J., 2005. Stationary Monetary Equilibrium in a Baumol-Tobin Exchange Economy: Theory and Computation. Georgetown University Working Paper. Baumol, W., 1952. The transaction demand for cash: an inventory theoretic approach. The Quarterly Journal of Economics 66, 545-556.

Bee, A., Meyer, B., Sullivan, J. Micro and macro validation of the consumer expenditure survey. In: Carroll, C., Crossley, T., Sabelhaus, J. (Eds.), Improving the Measurement of Consumer Expenditures, University of Chicago Press, forthcoming.

Bewley, T., 1980. The optimum quantity of money. In: Kareken, J.H, Wallace, N. (Eds.), Models of Monetary Economies.

Bewley, T., 1983. A difficulty with the optimum quantity of money. Econometrica 51, 1485-1504.

Chatterjee, S., Corbae, D., 1992. Endogenous market participation and the general equilibrium value of money. Journal of Political Economy 100, 615646. Chari, V., Christiano, L., Kehoe, P., 1996. Optimality of the Friedman rule in economies with distorting taxes. Journal of Monetary Economics 37. 203-223. Chiu, J., Molico, M., 2010. Liquidity, redistribution, and the welfare cost of inflation. Journal of Monetary Economics 57, $428-438$.

Cooley, T., Hansen, G., 1989. The inflation tax in a real business cycle model. American Economic Review 79, $733-748$.

Croushore, D., 1993. Money in the utility function: functional equivalence to a shopping-time model. Journal of Macroeconomics 15, 175-182

De Nardi, M., 2004. Wealth inequality and intergenerational links. Review of Economic Studies 71, 743-768.

Domeij, D., Heathcote, J., 2004. On the distributional effects of reducing capital taxes. International Economic Review 45, 523-554.

Dotsey, M., Ireland, P., 1996. The welfare costs of inflation in general equilibrium. Journal of Monetary Economics 37, $29-47$.

Erosa, A., Ventura, G., 2002. On inflation as a regressive consumption tax. Journal of Monetary Economics 49, 761-795.

Feenstra, R., 1986. Functional equivalence between liquidity costs and the utility of money. Journal of Monetary Economics $17,271-291$.

Greenwood, J., Hercowitz, Z., Huffman, G., 1988. Investment, capacity utilization, and the real business cycle. American Economic Review 78, 402-417.

Heathcote, J., 2005. Fiscal policy with heterogenous agents and incomplete markets. Review of Economic Studies 72, $161-188$.

Heathcote, J., Storesletten, K., Violante, G., 2009. Quantitative Macroeconomics with Heterogeneous Households. NBER Working Paper 14768.

Heller, W., 1974. The holding of money balances in general equilibrium. Journal of Economic Theory 7, 93-108.

Imrohoroglu, A., Prescott, E., 1991. Seigniorage as a tax: a quantitative evaluation. Journal of Money Credit and Banking $23,462-475$.

Imrohoroglu, A., 1992. The welfare cost of inflation under imperfect insurance. Journal of Economic Dynamics and Control 16, 79-91.

Kaplan, G., Violante, G., 2011. A Model of the Consumption Response to Fiscal Stimulus Payments. NYU Working Paper.

Krueger, D., Perri, F., 2006. Does income inequality lead to consumption inequality? Evidence and theory. Review of Economic Studies 73, 163-193.

Lucas, R., 1982. Interest rates and currency prices in a two-country world. Journal of Monetary Economics 10, $335-359$.

McCallum, B., Goodfriend, M., 1987. The demand for money: theoretical studies. In: Newman, P., Milgate, M., Eatwell, J. (Eds.), The New Palgrave

DictơfrFaronomics, Houndmills, pp. 775-781.

Mulligan, C., Sala-i-Martin, X., 2000. Extensive margins and the demand for money at low interest rates. Journal of Political Economy 108, 961-991.

Paiella, M., 2001. Limited Financial Market Participation: a Transaction Cost-based Explanation. IFS working paper 01/06.

Romer, D., 1986. A simple general equilibrium version of the Baumol-Tobin model. The Quarterly Journal of Economics 101, 663-686.

Scheinkman, J., Weiss, L., 1986. Borrowing constraints and aggregate economic activity. Econometrica 54, $23-45$.

Stokey, N., Lucas, R., 1987. Money and interest in a cash-in-advance economy. Econometrica 55, 491-514.

Storesletten, K., Telmer, C., Yaron, A., 2007. Asset pricing with idiosyncratic risk and overlapping generations. Review of Economic Dynamics 10, 519-

548. Svensson, L., 1985. Money and asset prices in a cash-in-advance economy. Journal of Political Economy 93, 919-944.

Swanson, E., 1985. Risk aversion and the labor margin in dynamic equilibrium models. American Economic Review, American Economic Association 102 (June (4)), $1663-1691$.

Telyukova, I., 2011. Household need for liquidity and the credit card puzzle. MPRA Paper 6674, University Library of Munich, Germany.

Telyukova, I., Wright, R., 2008. A model of money and credit, with application to the credit card debt puzzle. Review of Economic Studies 75, 629-647.

Tobin, J., 1956. The interest elasticity of transactions demand for cash. The Review of Economics and Statistics 38, 241-247.

Vissing-Jorgensen, A., 2002. Towards an Explanation of the Households Portfolio Choice Heterogeneity: Non Financial Income and Participation

CostStructure. NBER Working Paper 8884 